УДК 637.115

(C) 2016

Палій А. П., кандидат сільськогосподарських наук

Харківський національний технічний університет сільського господарства ім. П. Василенка

\title{
ВСТАНОВЛЕННЯ ВПЛИВУ ДОЇЛЬНИХ СИСТЕМ НА КОРІВ ПІД ЧАС ДОЇННЯ
}

\section{Рецензент - кандидат сільськогосподарських наук К. В. Іщенко}

Поглиблене знання закономірностей основних фізіологічних функцій лактуючого організму високопродуктивних корів є могутнім засобом у стимулячії молочної продуктивності $i$, таким чином, у підвищенні використання генетичного потенціалу тварини. Адекватне та ефективне доӥння високопродуктивних корів полягає в тому, щчоб найбільш дочільно використовувати фізіологічні реакиії організму, які лежать в основі утворення молока $і$ молоковіддачі. Під час розробки та оцінювання системи щуадного доӥння корів необхідно враховувати вплив на соски вимені корів не лише таких ознак, як молочна продуктивність дійного стада, утримання соматичних клітин в молоці, динаміка молоковіддачі, пікова швидкість молоковіддачі та час доӥння, але й приділяти увагу стану сосків вимені із урахуванням їх зв'язку з іншими ознаками. Оперативне виявлення і усунення чинників, щуо негативно впливають на організм тварин під час машинного доӥнн є передумовою забезпечення ефективного використання дійного стада.

Ключові слова: доӥльна установка, корова, доїння, вплив, соски вимені, класифікація.

Постановка проблеми. В останні роки вирішення проблеми зниження мікрофлори в молоці особливих труднощів не викликає: побудовані нові тваринницькі об'єкти із сучасним доїльним обладнанням; технологічні карти виробництва молока передбачають обов'язкову санітарну обробку вимені тварин перед доїнням із використанням міжнародно визнаних дезінфікуючих засобів; тварини групуються по секціям у відповідності до стану їх здоров'я і стадії лактації; перед надходженням молока на молокопереробні підприємства воно охолоджується безпосередньо у господарстві до температури $4{ }^{\circ} \mathrm{C}$. Завдяки цьому все більша частка сільськогосподарських підприємств виробляє молоко з утриманням мікрофлори на рівні європейських стандартів $[2,7,10]$.

Виробництво молока на тваринницьких фермах у великій мірі залежить від ефективності функціонування технологічної системи машинного доїння корів, що включає в себе тварин, доїльну установку та обслуговуючий персонал. Ефективність функціонування системи залежить від своєчасного та якісного виконання технологічних операцій операторами, від типу, конструк- ції, параметрів і режимів роботи доїльної установки, iï вузлів і систем, від своєчасного і якісного виконання слюсарями-наладчиками контрольних і обслуговуючих операцій за доїльною установкою [4].

Машинне доїння впливає на стан вимені корів наступним чином: механічне перенесення хвороботворних мікроорганізмів від однієї тварини до іншої, зворотного току молока в доїльному апараті та в молокопроводі, пошкодження тканин вимені, особливо в області соска та соскового каналу.

Стан сосків вимені дійних корів - це показник організації рутини доїння і індикатор ризику появи інфекцій. Чим більше бактерій на кінчику соска, тим вище ризик занесення інфекції. Тріщини і садна на сосках - це місця розмноження бактерій. Вони можуть заподіяти корові біль, змушуючи іiі брикатися, частіше випорожнюватися під час доїння і знижувати молоковіддачу.

Тріщини сосків виникають в результаті поганого догляду за вим'ям. Знижується еластичність шкіри за сирої і брудної підстилки. Шкіра сосків не має сальних залоз і тому легко висихає, особливо у вітряні та спекотні дні. Тоді виникає набрякання i хворобливість соска, потім утворюються невеликі тріщини, які стають глибшими і кровоточать, вони забруднюються і покриваються кіркою. За таких умов корова видоюється не повністю, у неї розвивається мастит $[1,5,8]$.

Аналіз останніх досліджень і публікацій, у яких започатковано розв'язання проблеми. Для управління технологічними процесами на молочних комплексах необхідні кількісні експрес-методи контролю за виконанням технологічних операцій, що дають результат у режимі реального часу i забезпечують можливість швидкої оцінки їх впливу на організм дійних корів.

Останні роки серед дослідників в області фізіології машинного доїння особливий інтерес викликає проблема дії доїльного обладнання на організм корови. Небезпечність впливу доїльного апарату на стан здоров'я вимені корів базується на двох аспектах: він може пошкоджувати шкіру сосків або розповсюджувати бактерії, які викликають запалення [3]. 


\section{СІЛЬСЬКЕ ГОСПОДАРСТВО. ТВАРИННИЦТВО}

У результаті проведених досліджень доведено, що доїльне обладнання за дворазового доїння необхідно відключати у випадку зниження потоку молока до 400-500 мл/хв, за триразового доїння - 700 мл/хв [6, 9]. Завдяки такому режиму доїння вдається не лише знизити травмуючу дію вакууму на кінчики сосків, але й натренувати у корів швидку молоковіддачу та попередити зниження їх надоїв.

Поглиблене знання закономірностей основних фізіологічних функцій лактуючого організму $є$ могутнім засобом у стимуляції молочної продуктивності і, таким чином, у підвищенні використання генетичного потенціалу тварини. Без обліку та характеристики регуляторних механізмів, що лежать в основі лактаційної діяльності організму тварини, важко організувати правильну, фізіологічно обгрунтовану форму використання молочної худоби і домогтися подальшого стійкого підвищення молочної продуктивності тварин.

Метою досліджень $є$ встановлення ступеню впливу доїльного обладнання на дійних корів 3 розробкою класифікації стану сосків вимені.

Завдання досліджень - розробка інноваційного підходу у визначенні стану сосків вимені та впливу на них доїльних систем.

Матеріали і методи досліджень. Об'єктом досліджень були тварини української чорнорябої молочної породи великої рогатої худоби. Науково-господарські досліди проводили в умовах ДПДГ «Кутузівка» НААН України Харківського району Харківської області за безприв'язного утримання дійного стада на глибокій довгонезмінній солом'яній підстилці та дворазового доїння на добу на вітчизняній доїльній установці типу «Ялинка» УДЯ - 16А (2×8) виробництва АО «Брацлав».

Результати досліджень. Адекватне та ефективне доїння високопродуктивних корів полягає в тому, щоб найбільш доцільно використовувати фізіологічні реакції організму, які лежать в основі утворення молока і молоковіддачі. Правильна організація машинного доїння дає змогу значно підвищити продуктивність праці та отримувати молоко високої якості.

У практиці молочного тваринництва нерідко доводиться стикатися 3 гальмуванням рефлексу молоковіддачі, викликаним впливом на корову різних стрес-факторів перед початком або ж у ході доїння. Неповноцінний прояв рефлексу молоковіддачі може бути викликаний зміною безумовнорефлекторного впливу на молочну залозу - неадекватна стимуляція, біль, або умовнорефлекторного - порушення стереотипу доїння.

Згідно із сучасним уявленням і фізіологічним доказом наявності в залозі різноманітних рецепторів, що сприймають механічні, термічні, хімічні подразнення, імпульси від них досягають гіпоталамуса та інших відділів, включаючи кору головного мозку.

Ці теоретичні дають підставу розглядати деякі практичні уявлення з урахуванням навантаження на рецепторний апарат.

На рисунку представлений вплив доїльного обладнання на соски вимені корів. Зміни, що 3'явилися тільки на голівці соска, зазвичай є наслідком «холостого» доїння або викликані занадто різким масажем дійкової гуми, що в свою чергу може бути наслідком занадто високого тиску вакууму або занадто жорсткого гумового виробу. На гостроносих сосках легше з'являються пошкодження, ніж на рівних. Це обумовлено способом масажу дійкової гуми.

На корні соска і на соску з'явилися зміни кольору, які могли стати наслідком невідповідної дійкової гуми або холостого доїння. Якщо ободок дійкової гуми знаходиться занадто високо по відношенню до довжини соска, або дійкова гума занадто велика для даної товщини соска, кровообіг під час доїння може бути ускладнений.

Розроблена класифікація впливу доїльних систем на основі інноваційного підходу представлена в таблиці.

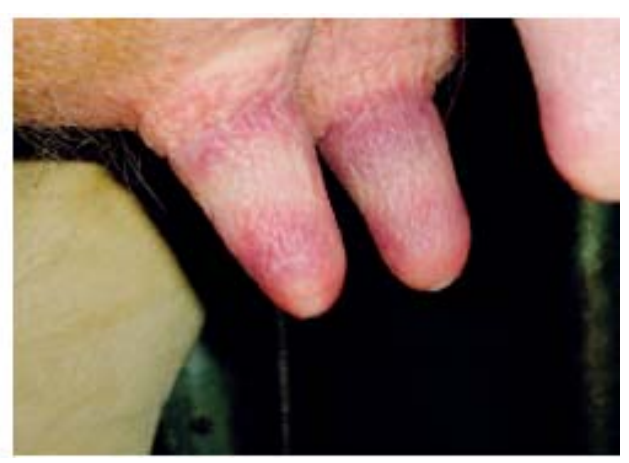

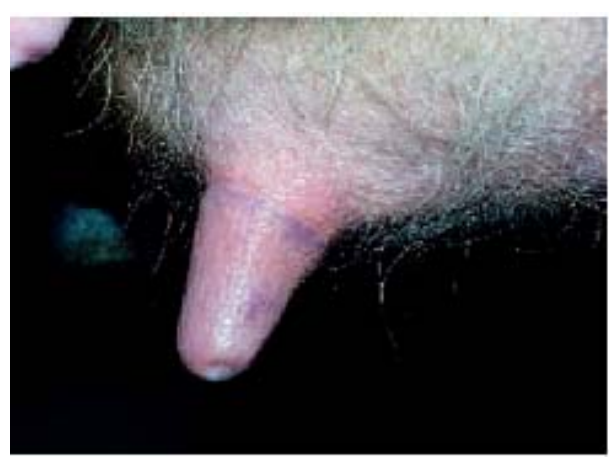

Зміни на сосках вимені корів внаслідок доїння 
СІЛЬСЬКЕ ГОСПОДАРСТВО. ТВАРИННИЦТВО

\section{Класифікація стану сосків}

\begin{tabular}{|c|c|c|c|}
\hline Клас & Опис & Допустимо & Не допустимо \\
\hline I & $\begin{array}{c}\text { Чиста, гладка шкіра, без зміни кольору, м'яка головка } \\
\text { соска, біле кільце допускаєтья лише в якості зміни } \\
\text { кольору }\end{array}$ & $>70-80 \%$ & $<60 \%$ \\
\hline II & $\begin{array}{c}\text { Видимі ознаки від навантаження, але без розривів, } \\
\text { випнутий та білий сосковий отвір, зміна кольору на } \\
\text { шкірі соска }\end{array}$ & $20-30 \%$ & $>40 \%$ \\
\hline III & $\begin{array}{c}\text { Струпи, кривава, пошкоджена шкіра. Тверда та набух- } \\
\text { ла головка соска, загублена еластичність тканини }\end{array}$ & $<3 \%$ & $>10 \%$ \\
\hline
\end{tabular}

Таким чином, під час розробки та оцінювання системи щадного доїння корів необхідно враховувати вплив на соски вимені корів не лише таких ознак, як молочна продуктивність дійного стада, утримання соматичних клітин в молоці, динаміка молоковіддачі, пікова швидкість молоковіддачі та час доїння, але й приділяти увагу стану сосків вимені із врахуванням їх зв'язку 3 іншими ознаками.

\section{Висновки:}

1. Неправильне машинне доїння корів веде до неповного видоювання i нанесення больових подразнень на рецептори вимені. Водночас на

\section{БІБЛІОГРАФІЯ}

1. Верещагин Д. Правильное доение: гигиенические аспекты [текст] / Д. Верещагин // АгроСнабФорум. - 2006. - №8. - С. 34.

2. Кук $K$. Санація дійок як метод профілактики маститу у корів [текст] / К. Кук // Ветеринарна практика. - 2013. - №2 (76). - С. 36-39.

3. Луценко М. Дослідження процесу доїння корів у спеціалізованих доїльних залах [текст] / М. Луценко, Д. Зволейко // Техніка і технології АПК. - 2012. - №9 (36). - С. 31-34.

4. Палій А. П. Інноваційні основи одержання високоякісного молока : монографія [текст] / А. П. Палій. - Х. : Міськдрук. -2016. - 270 с.

5. Палій А. П. Інноваційний підхід в оцінці чистоти вимені корів [текст] / А. П. Палій // Науковотехнічний бюлетень 115. - Х., 2016. - С. 165-169.

6. Палій А. П. Інновації у визначенні якості здійснення підготовчих операцій до доїння [текст] / А. П. Палій // Таврійський науковий віс- сосках відбуваються небажані видимі зміни.

2. Пропонується використовувати класифікацію стану сосків вимені корів під час підбору тварин до промислового використання.

Перспективи подальших досліджень. Потрібно продовжувати вивчення адаптивних реакцій корів, щоб підвищити їх продуктивність і знизити виробничі витрати. Оперативне виявлення і усунення чинників, що негативно впливають на організм тварин під час машинного доїння $\epsilon$ передумовою забезпечення ефективного використання дійного стада.

ник. - Херсон, 2015. - №93. - С. 144-148.

7. Палий А. П. Санитарно-гигиенические условия получения молока [текст] / А. П. Палий, А. П. Палий // Известия Великолукской государственной сельскохозяйственной академии. - Великие Луки, 2016. - №1 (13). - С. 33-39.

8. Assessing the scale of teat end problems and their likely causes [text] / [Ohnstad I. C. et. al.] // Proc. $42^{\text {nd }}$ Ann. Mtg. Natl. Mastitis Council. Texas, 2003. - P. 128-135.

9. Mein G. A. Effects of milking on teat-end hyperkeratosis: mechanical forces applied by the teatcup liner and responses of the teat [text] / G. A. Mein, D. M. Williams, D. J. Reinemann // Proc. $42^{\text {nd }}$ Ann. Mtg. Natl. Mastitis Council. Texas, 2003. - P. 114-123.

10. Milking regimes to shorten milking duration [text] / [Clarke T. et. al.] // J. Dairy Res. - 2004. Vol. 71. - P. 419-426. 